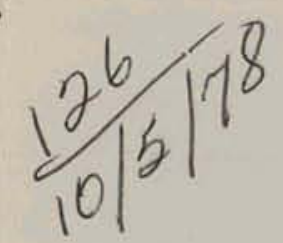

\title{
WMSTER

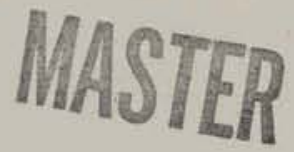

\section{ENERGY DEMAND ANALYSIS IN THE WORKSHOP ON ALTERNATIVE ENERGY STRATEGIES}

\author{
Steven C. Carhart
}

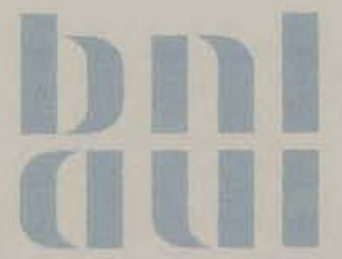

April 1978

ECONOMIC ANALYSIS DIVISION

NATIONAL CENTER FOR ANALYSIS OF ENERGY SYSTEMS

BROOKHAVEN NATIONAL LABORATORY

ASSOCIATED UNIVERSITIES, INC. UNDER CONTRACT NO. EY-76-C-02-0016 WITH THE

UNITED STATES DEPARTMENT OF ENERGY 


\section{DISCLAIMER}

This report was prepared as an account of work sponsored by an agency of the United States Government. Neither the United States Government nor any agency Thereof, nor any of their employees, makes any warranty, express or implied, or assumes any legal liability or responsibility for the accuracy, completeness, or usefulness of any information, apparatus, product, or process disclosed, or represents that its use would not infringe privately owned rights. Reference herein to any specific commercial product, process, or service by trade name, trademark, manufacturer, or otherwise does not necessarily constitute or imply its endorsement, recommendation, or favoring by the United States Government or any agency thereof. The views and opinions of authors expressed herein do not necessarily state or reflect those of the United States Government or any agency thereof. 


\section{DISCLAIMER}

Portions of this document may be illegible in electronic image products. Images are produced from the best available original document. 
BNL 50863

UC-95a

(Energy Conservation-Utilization

and Information Dissemination - TID-4500)

\title{
ENERGY DEMAND ANALYSIS IN THE WORKSHOP ON ALTERNATIVE ENERGY STRATEGIES
}

\author{
Steven C. Carhart
}

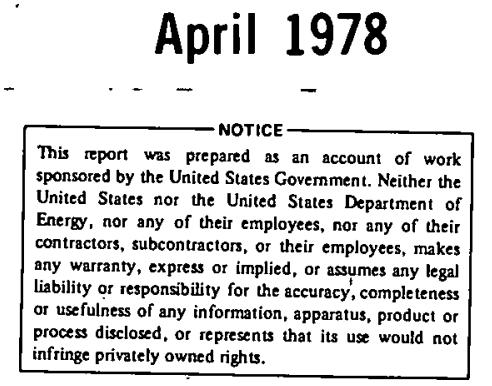

RESEARCH CARRIED OUT PARTIALLY BY RESOURCES FOR THE FUTURE, WASHINGTON, D.C. AND ALSO UNDER THE AUSPICES OF

THE UNITED STATES DEPARTMENT OF ENERGY, CONTRACT NO. EY-76-C-02-0016. NATIONAL CENTER FOR ANALYSIS OF ENERGY SYSTEMS

BROOKHAVEN"NATIONAL LABORATORY UPTON, NEW: YORK 11973 
This report was prepared as an account of work sponsored by the United States Government. Neither the United States nor the United States Department of Entrgy (DOE), nor any of their employees, nor any of their contractors, subcontractors, or their employees, makes any warranty, express or implied, or assumes any legal liability or responsibility for the accuracy, completeness or usefulness of any information, apparatus, product or process disclosed, or represents that its usc would not infringe privately owned rights.

Printed in the United States of America Available from

National Technical Information Service U.S. Department of Commerce. 5285 Port Royal Road Springfield, VA 22161

Price: Printed Copy $\$ 4.00$; Microfiche $\$ 3.00$ 


\begin{abstract}
The Workshop on Alternative Energy Strategies, conducted from 1974 through 1977, was an international study group formed to develop consistent national energy alternatives within a common analytical framework and global assumptions. A major component of this activity was the demand program, which involved preparation of highly disaggregated demand estimates based upon estimates of energy consuming activities and energy requirements per unit of activity reported on a consistent basis for North America, Europe, and Japan. Comparison of the results of these studies reveals that North America requires more energy per unit of activity in many consumption categories, that major improvements in efficiency will move North America close to current European and Japanese efficiencies, and that further improvements in European and Japanese efficiencies may be anticipated as well. When contrasted with expected availabilities of fuels, major shortfalls of oil relative to projected demands emerge in the eighties and nineties. Some approaches to investment in efficiency improvements which will offset these difficulties are discussed.
\end{abstract}


Introduction

The Workship on Alternative Energy Strategies represented a unique experiment in international collaboration directed at a common global problem, specifically the growing shortages of energy in the forms and at the prices to which we have become accustomed, and the problem of managing a transition to an energy system consistent with emerging resource availabilities.

WAES was unique in its organization. As conceived by Professor Carroll Wilson of M.I.T., the Project Director, WAES brought together senior decision makers from government, industry, and academia for a non-official, ad hoc study. Each senior member (participant in WAES nomenclature) designated one or more members of his staff or personnel from a co-operating organization in his country to work essentially full time on WAES as his associate. The study began in the Fall of 1974 and concluded in the Spring of 1977 with the publication of its final report, Energy: Global Prospects 1985-2000. In addition to this overview report, WAES is publishing three technical volumes giving the details of the analy-

sis. The first of these, published late last year is Energy Demand Studies: Major Consuming Countries. This presents, in full detail, the national demand studies performed by the WAES national teams.

These demand studies were performed within an overall framework indicated in Figure 1. The WAES analysis differs from most other studies in that it was performed by national teams from each country using a common methodology.

Separate supply and demand studies were performed for a range of scenario case assumptions. For all cases, certain global assumptions were made concerning economic growth, oil price, and national policy 


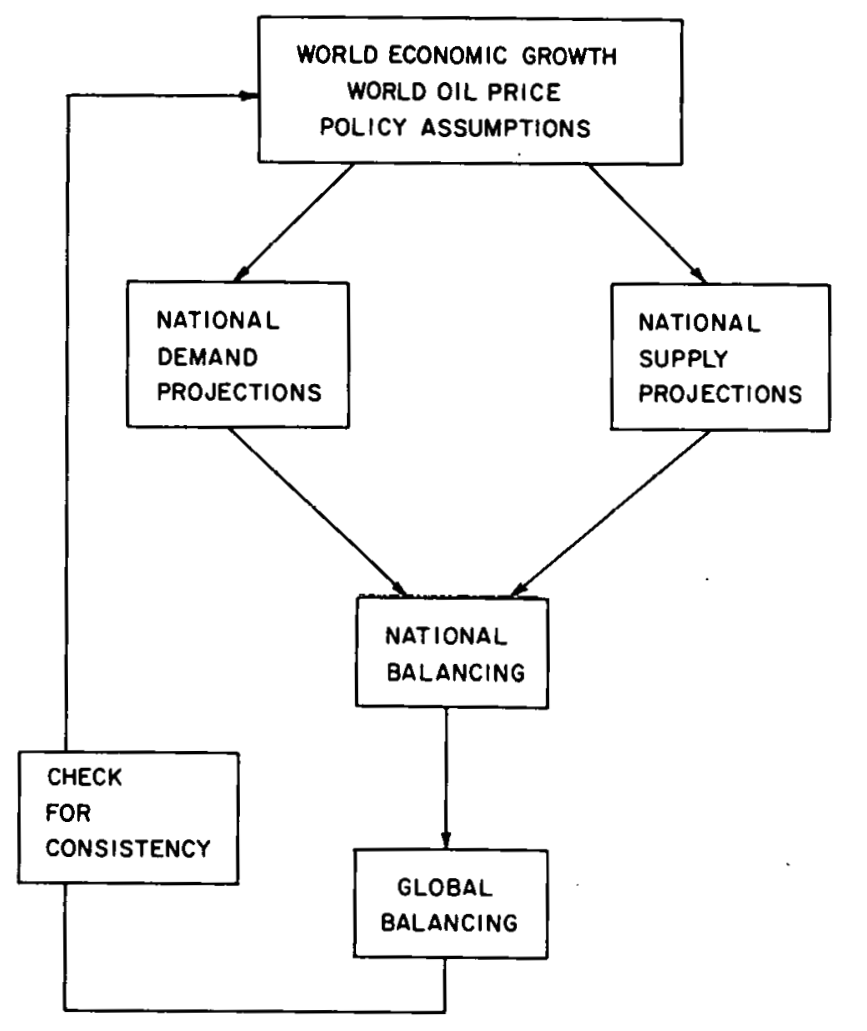

Figure 1. WAES methodology is based on projections based on common assumptions. 
response. For the period 1985-2000, additional input parameters included additions to world oil reserves, the principal replacement fuel for oil, and possible political ceilings on OPEC oil production. These are summarized in Figure 2.

For each global case, each national team would begin from the global assumptions and estimate what appropriate national parameters would be in those circumstances. Thus, for a given rate of growth in GWP, an individual country might be higher or lower according to the judgement of the national team.

For these parameters, national energy demand and supply estimates were developed as shown in Figure 1. These were then integrated at the national level. The fuel deficits were assumed to be covered by imports and unused domestic supply was assumed to be available for export. Global exports and imports were balanced to test for adequacy of supply. We will discuss this in more detail later, but first let us look closely at demand analysis.

\section{WAES Demand Studies}

The demand projections performed in WAES have several distinctive features. First, they were performed by national teams with special knowledge of the national situations in the various WAES countries. The individuals involved are listed in an appendix. Second, the analyses were performed using a common methodology and framework.

The first principle of this methodology was to separate projections of the mix of energy consuming activities from the intensity of each activity. Separate estimates were made for sixty-nine sectors of activity levels and energy intensities, for both the base year of 1972 and for the year 1985 under the various scenario assumptions. Thus, for each sector, 


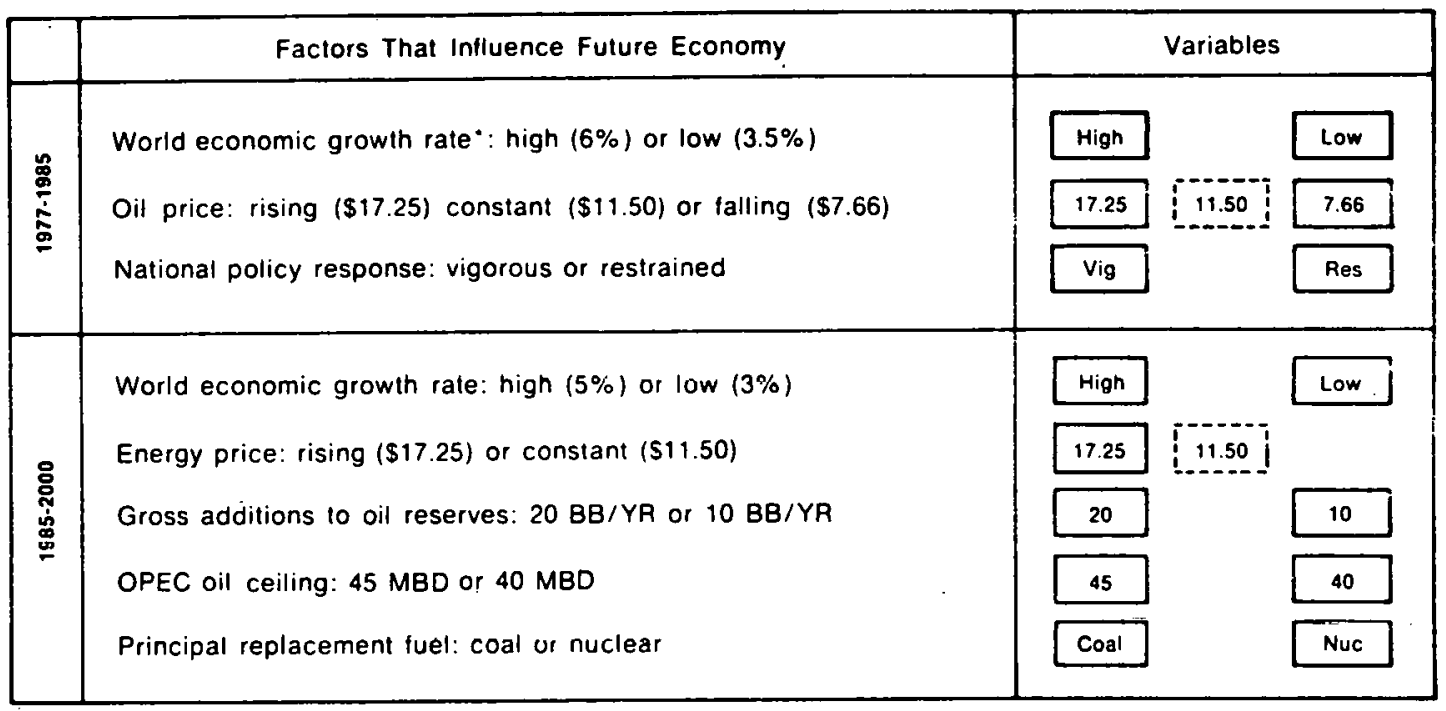

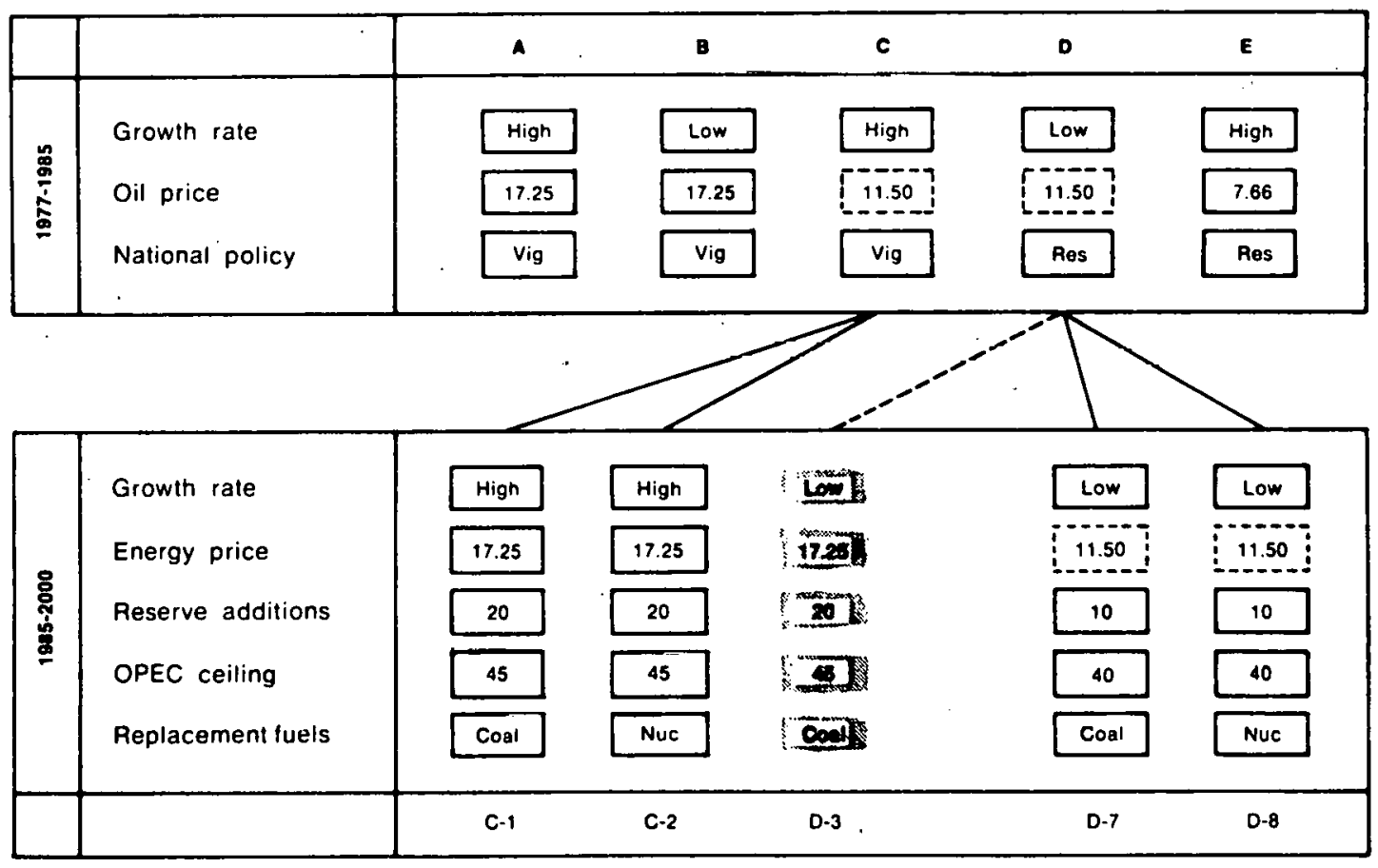

- The period from 1973 to the end of 1975 is assumed to correspond to actual world economic conditions, with recovery to 1973 levels by the end of 1976 postulated.

National economic studies done under these assumptions, when summed. aclually result in global rates of 5.2 and $3.4 \%$ to 1985 and 4.0 and $2.8 \%$ from 1985 to 2000 .

Figure 2. WAES global case assumptions. 
energy demand was estimated according to the equation:

Delivered energy = Activity level $\mathrm{x}$ energy/unit activity .

With the overall global scenario of growth, price, and government policy, each national team developed an appropriate national economic and demographic projection which was used to estimate WAEs activity levels. Energy intensities were developed for the same scenario variables, taking into account what types of conservation technologies are justified by the case prices and how fast they might be introduced under the case assumptions concerning prices and government policies.

From these estimates of activity levels and energy intensities, demand totals were built up as shown in Figure 3. The exact categories used in this disaggregation are shown in an appendix.

This general approach was motivated to a large degree by the well known fact that there exists among developed countries a range of about a factor of two in their energy/output relationships, as shown in Figure 4. We wanted to know the underlying causes of these differences; how they might change over time; and to what degree the energy saving techniques of one country might be transferred to others. We developed this approach of disaggregation involving separation of activity projections and energy per unit activity projections to facilitate such investigastions. Full results of the WAES demand studies upon which this paper is based are reported in reference (1).

The first major differences between countries can be seen in the 1972 sector breakdowns shown in Table 1 .

A few major conclusions can be drawn from these aggregated totals. Transportation is clearly a far more important factor in energy consumption in North America than in either Europe or Japan. This is due to a combination 

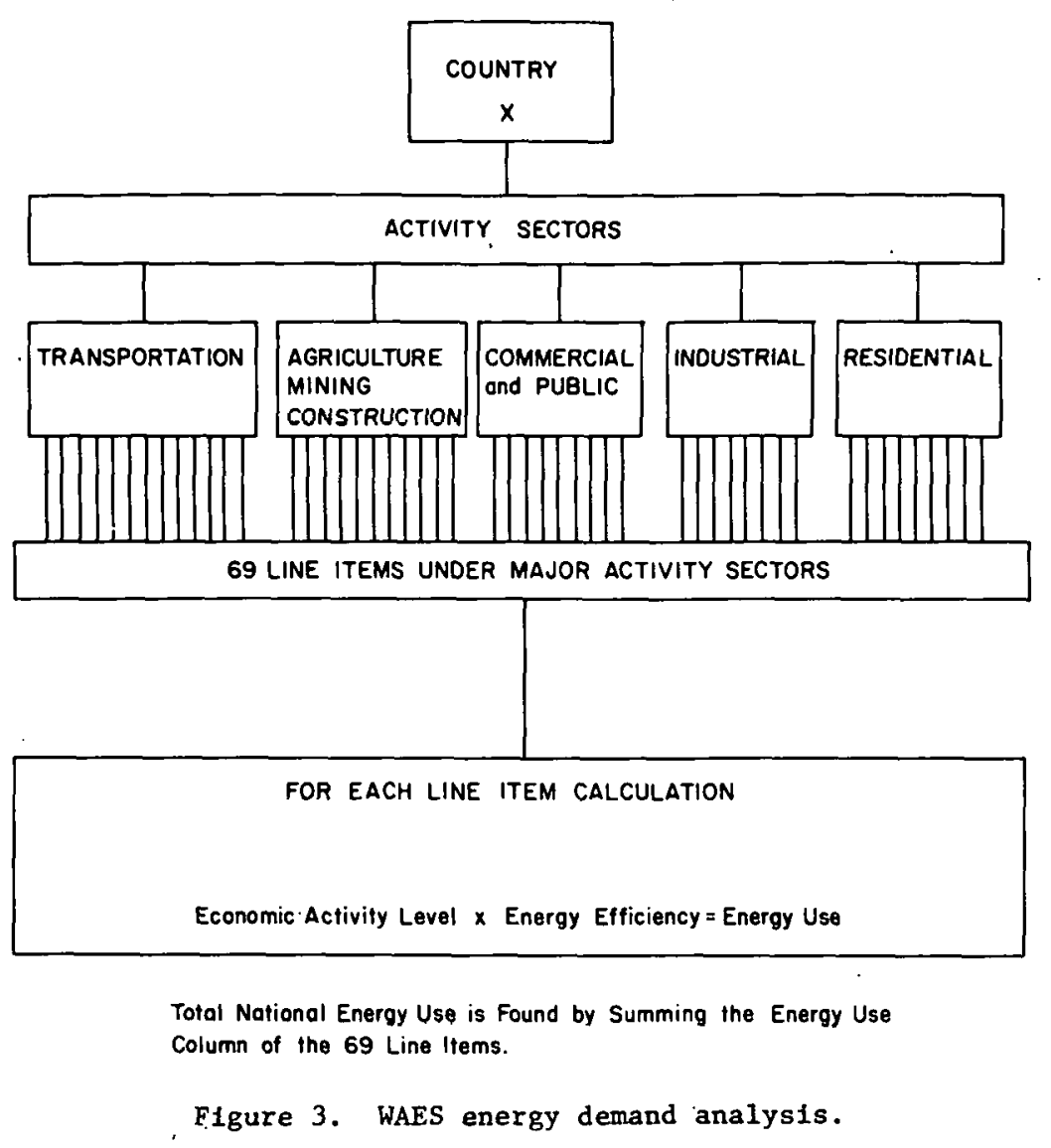

$-6-$ 


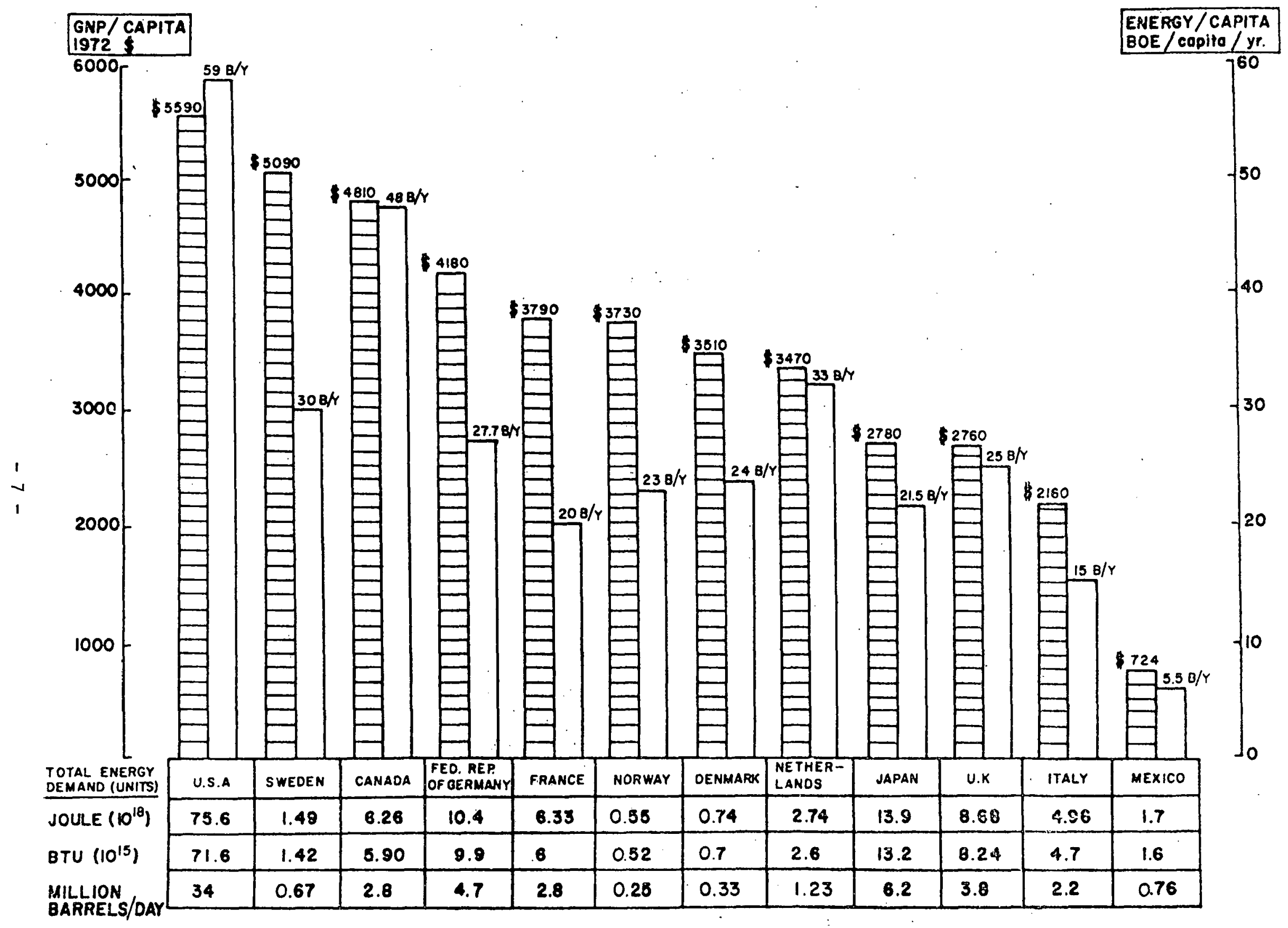

F1gure 4. WAES countries, energy/capita and GNP/capita 1972. 
Table 1

1972 Sector Breakdowns, percent

Country

Canada
Denmark
Finland
France
W. Germany
Italy
Japan
Mexico
Netherlands
Norway
Sweden
United Kingdom
United States

Industry Transport

28.4

26.7

21.7

14.1

23.1

18.2

18.2

39.2

18.2

49.0

21.0

41.2

37.1

22.0

31.3

43.3

20.8

37.7

17.8

36.7

18.9

27.0

32.0
Comm/Public

Residential

FAMC

22.5

(1)

10.2

6.0

12.3

34.9

4.9

(2)

(3)

27.4

(4)

(5)

38.9

9.5

25.2

4.9

9.6

7.1

23.0

2.5

9.9

8. 5

8.4

4.6

8.5

8.1

13.5

(6)

(6)

7.6

21.9

6.7

10.8

6.7

19.3

6.4

3.5

13.0

25.3

2.7

3.4

5.6

23.1

6.1

9.4

7.8

21.4

3.8

7.9

(Processing losses excluded. Fossil fuel/electriclty mix varies between countries.)

1. Not spectifled.

2. Included In Industrial.

3. Included in Residential.

4. Fishing and agriculture included in Residential. Mining and construction included in Industrial.

5. Included in Industrial.

6. Included in Commercial and Public. 
of greater distances; less efficient transportation technologies; and a less efficient mix of transportation modes. More detailed statements can be made based on the disaggregated data.

Second, industrial use of energy is of far greater relative importance In Europe and Japan. This is perhaps due more to North American transport inefficiency than any characteristics of energy use in industry overseas, since many industries abroad are more efficient than their American counterparts.

Countries with warmer climates such as Italy and Mexico can be seen to use relatively little energy in their buildings as might be expected. Japan's low consumption in buildings can be attributed in large measure to the lower space available per person due to high population densities. Northerly industrial countries with lower population densities have greater requirements for buildings, though these vary within this group due to different standards of comfort, area per person, structural standards, and HVAC equipment.

However, these structural characteristics are likely to change. The growth in different sectors is anticipated to be very different. Table 2 summarizes these trends for case $C$, which assumes constant real prices and the implementation of vigorous conservation policies in all countries.

A few tentative conclusions can be drawn from these relative growth rates. For most countries, industrial energy growth rates approximate the overall total growth rate. Opportunities for improved efficiency in this sector are evidently typical of the economies as a whole. Iransportation growth rates for most countries are generally above average, suggesting limited opportunities for improvement. The major exception to this is the United States, for which the transportation growth rate is well below the average. This largely reflects the major improvements which can 
Table 2

Sector Growth Rates for Dellvered Energy

1972 - 1985, Case C

\begin{tabular}{|c|c|c|c|c|c|c|c|c|}
\hline \multicolumn{2}{|l|}{ Country } & Industry & Transport & Comm/Public & Residential & FAMC & Feedstocks & Total \\
\hline \multicolumn{2}{|l|}{ Canada } & 2.8 & 3.2 & 3.8 & 1.2 & (1) & 8.3 & 3.2 \\
\hline \multicolumn{2}{|l|}{ Denmark } & 2.1 & 3.6 & 1.4 & 0.5 & 3.3 & - & 2.0 \\
\hline \multicolumn{2}{|l|}{ Finland } & 4.3 & 4.9 & 3.2 & 1.5 & 1.5 & (2) & 3.5 \\
\hline \multicolumn{2}{|l|}{ France } & 2.7 & 3.5 & (3) & 2.3 & (4) & (5) & 2.7 \\
\hline \multicolumn{2}{|c|}{ W. Germany } & 2.3 & 1.8 & 2.9 & 1.3 & 1.8 & 3.7 & 2.2 \\
\hline \multicolumn{2}{|l|}{ Italg } & 3.6 & -0.4 & 2.6 & 2.3 & 6.5 & 6.6 & 3.2 \\
\hline \multicolumn{2}{|l|}{ Japan } & 5.6 & 6.9 & 6.1 & 5.3 & 2.7 & 3.7 & 5.7 \\
\hline \multicolumn{2}{|l|}{ Mexico } & 7.4 & 7.2 & 11.9 & 8.5 & 5.5 & 8.8 & 7.7 \\
\hline \multicolumn{2}{|c|}{ Netherlands } & 5.7 & 1.5 & 1.6 & 2.9 & 3.2 & 8.1 & 3.9 \\
\hline \multicolumn{2}{|l|}{ Norway } & 3.1 & 5.1 & 3.8 & $0 . \varepsilon$ & 1.8 & 5.8 & 3.3 \\
\hline \multicolumn{2}{|l|}{ Sweden } & 3.5 & 2.5 & 1.1 & -0.2 & 7.3 & 9.3 & 2.8 \\
\hline \multicolumn{2}{|c|}{ United Kingdom } & 1.3 & 1.9 & 0.6 & 1.4 & 0.4 & 3.7 & 1.6 \\
\hline \multicolumn{2}{|c|}{ United States } & 3.2 & 0.8 & 1.9 & -0.1 & 2.2 & 5.4 & 1.9 \\
\hline \multicolumn{9}{|c|}{ (processing losses excluded) } \\
\hline \multicolumn{9}{|c|}{$\begin{array}{l}\text { 1. Not specified. } \\
\text { 2. Included in Industrial. } \\
\text { 3. Included in Residential. } \\
\text { 4. Fishing and agriculture } \\
\text { Included in Industrial. } \\
\text { 5. Included in Industrial. }\end{array}$} \\
\hline
\end{tabular}


be made in U.S. automobile efficiencies. Commercial and Public trends are varied; these reflect a combination of varied growth rates in this sector as well as different climatic conditions and opportunities for improving building construction. Residential growth rates are generally below the averages; this situation reflects the fact that population in the developed countries is growing a good deal more slowly than GNP, and the fact that major improvements are possible in many residential buildings.

Although the relative importance of these different sectors is important, a far more important phenomenon is at work: a general reduction in the amount of energy required for increments of GNP. This can be expressed in terms of the energy coefficient, or the ratio of percentage growth in primary energy consumption (including processing losses) to percentage growth in GNP. This is true despite a gradual increase in electricity as a fraction of delivered energy in most countries.

As we have seen earlier, the average energy/GNP relationship varies by about a factor of two among industrialized countries. However, further conclusions energe from the detailed WAES projections: 1. In response to post-1973 oil price increases, the energy co-efficient associated with future growth will be less than pre-embargo figures; and 2. further increases in energy prices and strengthening of government conservation policies may be expected to further reduce the energy coefficient. Regional averages for the period $1965-72$ with world oil prices in the vicinity of $\$ 3.00$ per barrel ranged as high as 1.05 . Three WAES cases show the effects of these higher prices and conservation policies. Cases A, C, and $E$ shown in Table 3 are all high GWP growth cases. Case E, as noted in Figure 2, assumes that world oil prices fall from recent levels 
Table 3

Elasticity of Primary Energy Consumption With Respect to GNP WAES Cages, 1975-1985

\begin{tabular}{lrrr} 
& \multicolumn{1}{c}{$\mathrm{A}$} & $\mathrm{C}$ & $\mathrm{E}$ \\
\cline { 2 - 4 } Canada & .472 & .524 & .735 \\
Demmark & .551 & .729 & 1.086 \\
Finland & .479 & .692 & .889 \\
France & .410 & .563 & .895 \\
W. Germany & .597 & .659 & .737 \\
Italy & .378 & .613 & 1.122 \\
Japan & .848 & .878 & .944 \\
Mexico & 1.262 & 1.120 & 1.213 \\
Netherlands & 0.873 & 1.016 & 1.271 \\
Norway & 1.321 & 1.357 & 1.467 \\
Sweden & .747 & .898 & 1.215 \\
United Kingdom & .657 & .735 & .781 \\
United States & .458 & .562 & .894
\end{tabular}

All figures based on primary resource requirements, including processing losses.

Table 4

1972 Automobile Efficiencies

$\mathrm{MJ} / \mathrm{KM}$

$\begin{array}{ll}\text { CANADA } & 5.48 \\ \text { DENMARK } & 3.13 \\ \text { W. GERMANY } & 3.39 \\ \text { ITALY } & 3.2 \AA \\ \text { JAPAN } & 3.82 \\ \text { MEXICO } & 8.67 \\ \text { NETHERLANDS } & 3.24 \\ \text { NORWAY } & 3.25 \\ \text { SWEDEN } & 3.20 \\ \text { UNITED KINGDOM } & 3.33 \\ \text { UNITED STATES } & 5.55\end{array}$


of $\$ 11.50$ (1975 dollars) to $\$ 7.66$ by 1985 and minimum conservation policies are followed. Case $C$, with constant real prices at $\$ 11.50$ (1975 dollars) and vigorous conservation policies, shows much lower energy coefficients. Case A, with prices rising to $\$ 17.25 /$ barrel in 1975 dollars and yigorous conservation policies, results in even lower coefficients.

It is essential to emphasize that these coefficients are not projected on an aggregate basis, but instead are the results of assessments of the rate at which conservation technologies can b.e implemented in each of the sixty-nine WAES demand categories: for the economic growth, price, and policy assumptions of each. WAES case. Individual opportunities for transfers of conservation technologies can be identified through comparison of energy/ output relationships at the detailed level.

For example, Table 4 shows the 1972 efficiencies of automobiles from WAES countries. The United States, Canada and Mexico have automobile fleets which use approximately twice the energy per kilometer as is used in Europe and Japan. This is probably attributable for the most part to the higher energy prices in Europe and Japan (which of ten include high levels of tax) and the purchase taxes on automobiles common in these countries. The taxes typically rise steeply with weight, displacement, or horsepower.

The importance of prices in shaping the energy consuming technologies in developed countries is highlighted in Figure 6. Gasoline prices in Europe and Japan are approximately twice prevailing levels in North America, due in large part to taxes. Italy, which has the most efficient cars of any major country, has gasoline prices three times as high as those in North America. 

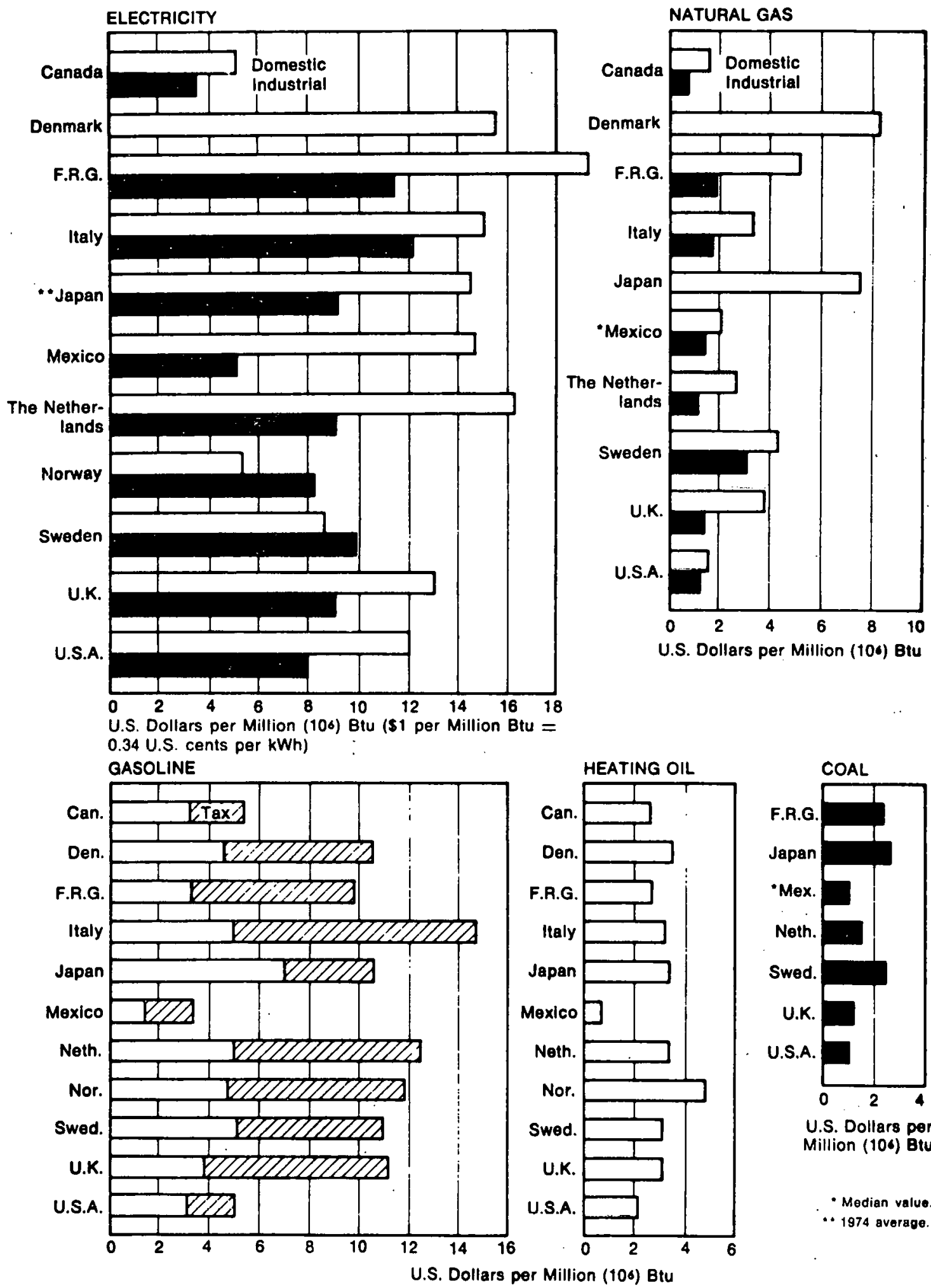

Figure 6. Selected energy prices comparison - mid- to late-1975. 
Not only do we find more efficient automobiles in Europe and Japan than we find in North America, we also find a greater emphasis on transport modes which are more efficient, mainly buses and railroads, as shown in Table 5 . Japan and most European countries also show less emphasis on energy-intensive air travel than one finds in North America. Unlike automotive technology which may be fairly readily transferred, these modal mixes are probably of limited relevance to current U.S. problems in view of the greater distances typical in this country. However, there may be lessons of considerable regional importance. The Japanese railroad system - which uses some of the world's most advanced railroad technology in the densely populated Tokyo-0saka corridor - may offer some ideas for redevelopment of railroads in the U.S. Northeast corridor despite its recent financial difficulties. Interpretation of energy efficiency data proved to be more difficult in the industrial sector. The only unit of output which could be consistently applied to all sectors was value added. Thus, data were reported in terms of energy per unit of value added. Many teams reported in addition energy per ton or other physical measure appropriate to each industry. Use of monetary measures of output naturally raises questions of conversion between countries. Since the Smithsonian agreement permitting floating exchange rates had been in effect for some time prior to 1972, all data are reported in terms of energy per 1972 dollar. This is based on the assumption that the floating market exchange rates provide a reasonable basis for calculating the relative value of output in different countries. The results of these calculations are summarized in Table 6 .

In most categories, we find a wide range of energy/value added figures. These can be attributed to a range of factors; product mix; production technology; age of plant; plant utilitzation rates; or other factors. Since 
Table 5

$$
1972 \text { Passenger - Km Per Capita }
$$

\begin{tabular}{|c|c|c|c|c|c|}
\hline & Auto & Bus & RAIL & AIR & TOTAL \\
\hline CAnada & 9761 & 553 & 147 & 995 & 11456 \\
\hline DENMARK & 6718 & 1480 & 597 & 840 & 9635 \\
\hline WEST GERMANY & 6772 & 1011 & 642 & 315 & 8710 \\
\hline ITALY & 4274 & 899 & 692 & 35 & 5900 \\
\hline JAPAN & 2166 & 1064 & 2955 & 125 & 6310 \\
\hline Mexico & $653^{(1)}$ & 760 & 76 & 126 & 1615 \\
\hline NETHERLANDS & 6257 & 666 & 650 & -- & 75 \\
\hline NORWAY & $4233^{(1)}$ & 979 & 531 & 232 & 59 \\
\hline SWEDEN & $7438^{(1)}$ & 853 & 561 & 1083 & \\
\hline UNITED KIngDOM & $5674^{(1)}$ & -- & 232 & 396 & \\
\hline UNITED STATES & $14347^{(2)}$ & 374 & 66 & 1293 & \\
\hline
\end{tabular}

No entry Indicates data unavailable.
(1) Assumes 1.7 average load factor.
(2) Based on 1.9 average load factor reported in DOT Nationwide Personal Transportation Survey.


Table 6

1972 Industrial Energy Intensities

MJ/1972 \$ Value Added

\begin{tabular}{|c|c|c|c|c|c|c|c|c|}
\hline & $\begin{array}{l}\text { IRON \& } \\
\text { SteEL }\end{array}$ & $\begin{array}{l}\text { NoN- } \\
\text { FERROUS }\end{array}$ & PAPER & $\begin{array}{l}\text { CHEM- } \\
\text { ICALS }\end{array}$ & $\begin{array}{l}\text { Mineral } \\
\text { Prod. }\end{array}$ & $\begin{array}{l}\text { FoOD } \\
\text { PROD, }\end{array}$ & $\begin{array}{l}\text { TRANS- } \\
\text { PORT } \\
\text { EQUIP. }\end{array}$ & Misc. \\
\hline CANADA & 94 & 126 & 171 & 96 & 129 & 30 & 16 & -- \\
\hline DenMark & 149 & 89 & 21 & 32 & 146 & 32 & 19 & 16 \\
\hline West Germany & 216 & 66 & 109 & 36 & 87 & 17 & 11 & 9 \\
\hline ITALY & 199 & 105 & 45 & 241 & 205 & 34 & 16 & 11 \\
\hline JAPAN & 287 & 114 & 128 & 176 & 143 & 19 & 5 & 50 \\
\hline NETHERLANDS & 234 & -- & 98 & 121 & -- & 27 & -- & 17 \\
\hline NoRWAY & 356 & 326 & 90 & 113 & 149 & 46 & 12 & -- \\
\hline SWEDEN & 119 & 94 & 418 & 28 & 91 & 21 & 13 & 17 \\
\hline UNITED KINGDOM & 200 & 47 & 26 & 73. & 190 & 26 & 16 & 21 \\
\hline UNited States & 243 & 118 & 125 & 98 & 114 & 30 & 11 & 13 \\
\hline
\end{tabular}

Notes: No entry indicates data unavailable.

All conversions made at 1972 U.N. exchange rates. 
these figures are reported on the basis of two-digit ISIC categories, the activities within any individual category are so heterogeneous that any comparisons must be made with great care.

Preliminary investigations into some of the figures showing wide divergence from median values in each industry gave some indication of how investigation might proceed. The low energy/output relationship in West Germany for mineral products is probably due in part to the widespread use of the dry process for cement manufacture in that country. The relatively high energy requirement for energy in the Italian chemical industry appears to stem in part from the fact that the industry has a high fraction of its production devoted to basic chemicals (rather than highly refined chemicals such as pharmaceuticals) which are produced in older plants. The low energy requirements in the Swedish steel industry are probably due in part to the production of highly processed, specialized alloys rather than more basic materials. Other key factors affecting thëse figures include the degree to which scrap is used for metal production; the labor intensity of various processes; and the mix of products within a twodigit sector in different countries. Further investigation is needed which will look in more detail below the two-digit level of aggregation in order to identify specific production approaches which may be transferable between nations. The data available at the two-digit level are useful primarily as a screening device for suggesting areas for more detailed study.

The final sector to be examined in detail is the residential sector, shown in Table 7. Space heating is the dominant component of these figures, and this accounts for the low requirements of warm countries such 
figures, and this accounts for the low requirements of warm countries such as Mexico and Italy, though other factors such as living space per person are also involved.

The main lesson of this table is the low requirements of countries such as Norway and Sweden compared with the U.S. and Canada, despite their having a colder climate on average. These differences arise from a set of building standards and lending practices which lead to much tighter construction and higher levels of insulation. Higher prices for heating oil also contribute to this phenomenon. With prices and building code requirements rising in the U.S., the Scandinavian experience suggests that - given time to turn over the building stock major improvements are possible in this sector.

\section{Table 7}

1972 Energy Per Dwelling $\left(10^{9} \mathrm{~J}\right)$

$\begin{array}{lr}\text { CANADA } & 196 \\ \text { DENMARK } & 122 \\ \text { W. GERMANY } & 93 \\ \text { ITALY } & 59 \\ \text { MEXICO } & 33 \\ \text { NETHERLANDS } & 139 \\ \text { NORWAY } & 84 \\ \text { SWEDEN } & 108 \\ \text { UNITED KINGDOM } & 77 \\ \text { UNITED STATES } & 180\end{array}$




\section{Energy Conservation in the Global Context}

As we noted earlier, for a given set of global scenario assumptions, each national team developed national supply and demand projections. These are then balanced, taking into account expected fuel mix, including maximum plausible movement away from the fuel form anticipated to be in short supply - oil. The excess of demand for each type of fuel over domestic supply becomes that nation's desired imports. Any excess of domestic supply over demand then becomes potential exports. The supply and balancing procedures are described in various WAES publications $(2,3,4)$ and will be summarized here in relation to their implications for energy conservation.

The availabilities and demands for all WAES countries and non-WAES countries except Comecon and China are combined in the global integrations illustrated schematically in Figure 7 . When the cumulative global demands for imports exceed available exports, the case "breaks," or becomes internally inconsistent. In the real world of course, this means that the case assumptions would no longer hold. This means that economic growth would fall, the oil price would increase, or more stringent policies would be required (or some combination of all three).

The most disturbing aspect of the WAES global integrations was that for a wide variety of case assumptions, a common pattern of oll shortfall emerged.

This is illustrated for two WAES cases. in Figure 8. For other assumptions, the behavior of oil supply and demand is the same but occurs at different times. The upper line indicates oil demand based on the WAES demand studies and fuel mixes, with appropriate adjustment for anticipated switches from oil. Oil supply is built up from the bottom of the chart, beginning with. non-OPEC sources. Most of the growth here stems from the addition of Alaskan North Slope and North Sea output to our supplies. 


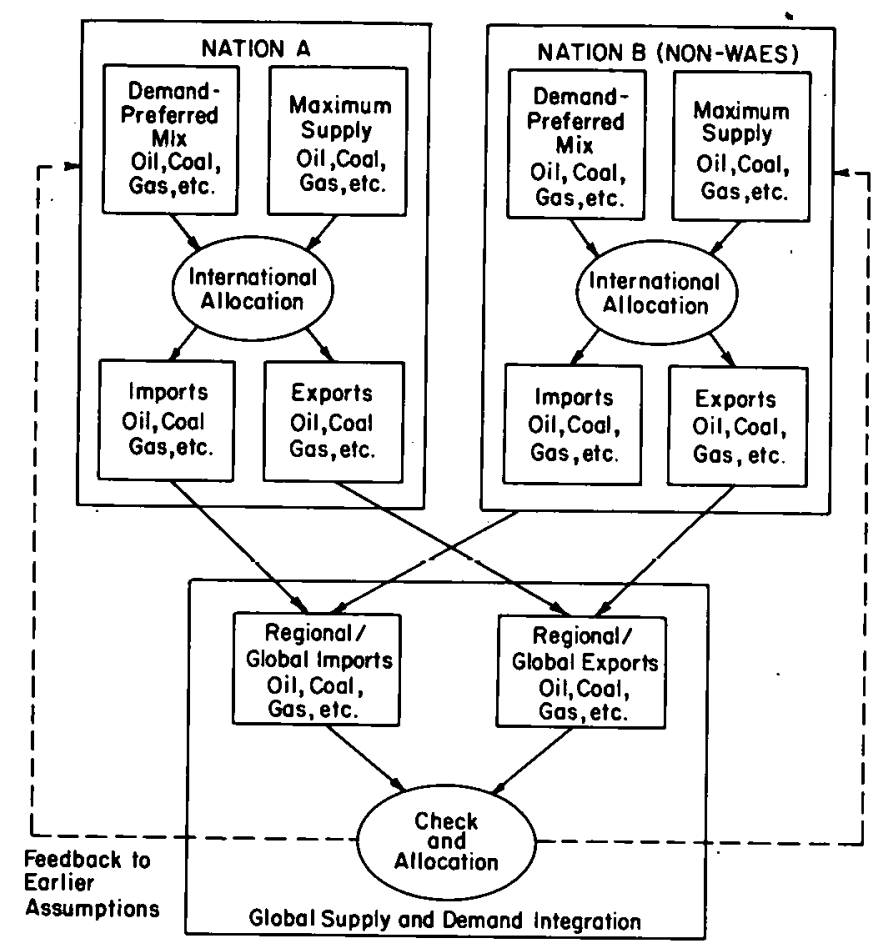

Figure 7. Supply-demand balance calculations: "unconstrained" integrations. 

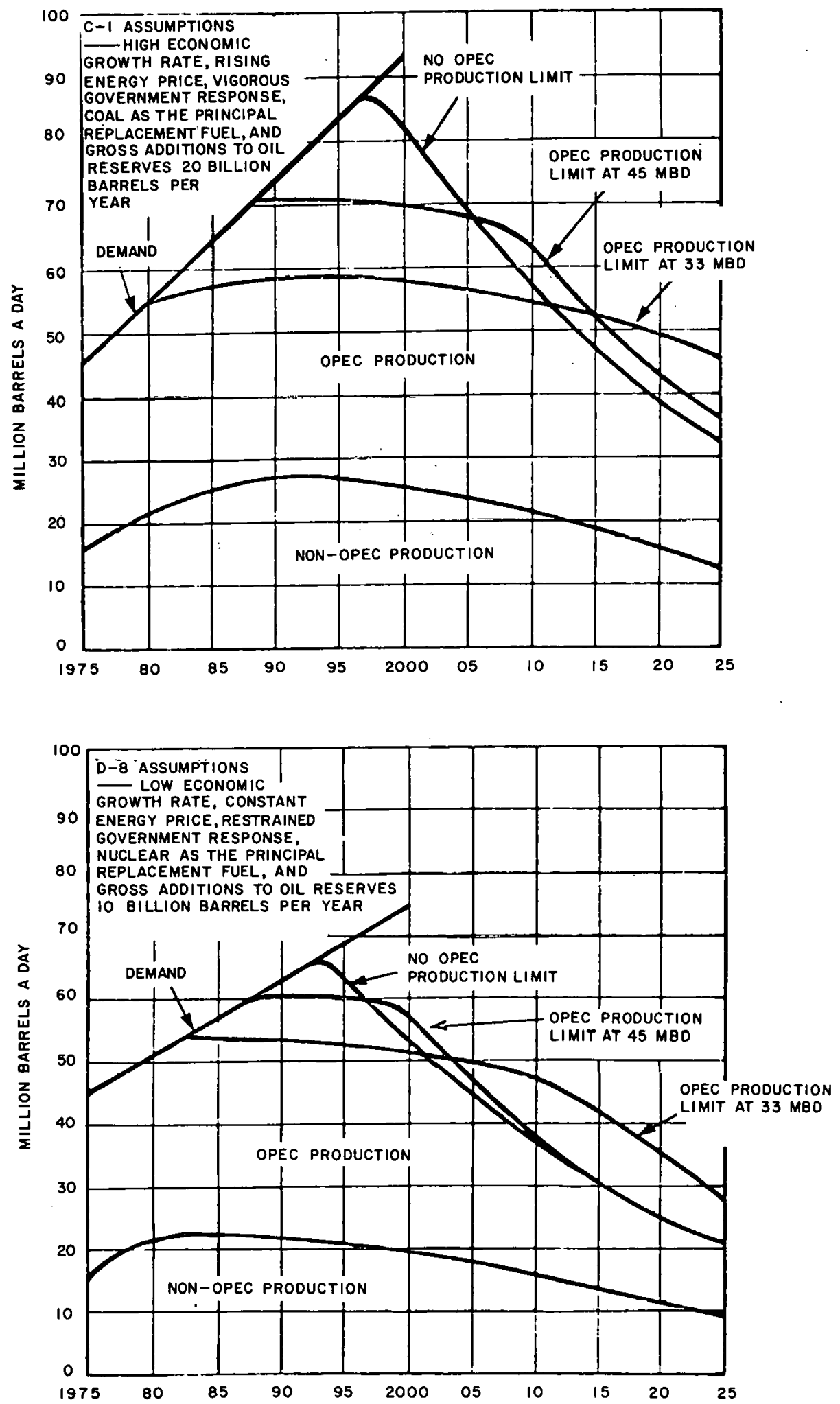

Figure 8. WOCA oil production for $\mathrm{C}-1$. 
The OPEC production figures include maximum anticipated production from OPEC nations with significant populations and the ability to absorb oil revenues in development programs. The balance of OPEC production comes from the "low absorbers" whose small populations and high oil reserves place them in a position of having no use other than overseas investment for their surplus oil revenues. These nations - principally the Arabian Peninsula nations: - have the option to place a political limit on their output. This could be motivated by internal political considerations such as conservation of oil reserves for future generations; or it could be part of the political bargaining process related to peace in the Middle East.

The various levels of political limits correspond to different possible political outcomes. The lowest level, 33 million b/d, corresponds to a continuation of current output in Saudi Arabia of around 9 million b/d.

Saudi Arabia's ultimate production is more than twice that amount, but even the maintenance of current levels is open to question.

If no political production ceiling is set, then anticipated demand exceeds available supply in 1996 - even with significant efforts at conservation and fuel switching. However, if political production ceilings are instituted, desired demand exceeds maximum available supply - perhaps as ear1y as. 1981 .

Of course, these potential "gaps." are artifacts of the WAES methodology and will not occur in reality; supply will equal demand. However, the adjustments which will be needed to equilibrate supply and demand - at growth price, and policy levels different from the case assumptions - may be very painful. These could include much lower economic growth rates; higher energy prices; or the need for severe energy policies. 
Thus, even with. substantial efforts at efficiency improvement and fuel switching, we can foresee a period of uncertain adequacy of oil supply commencing in the early eighties. The exact timing and effects of this period of tightness depend on the sequence of events leading to it - be they simple prorationing of OPEC production; an internal Saudi decision; or a cutoff as part of another Middle East conflict.

Demand Study Conclusions

Based on the results of the WAES demand studies, several conclusions can be drawn. These are interpretations solely of this author, as deadlines and other priorities did not permit WAES as a body to undertake detailed comparative analysis of these studies. I believe the principal conclusions we may draw are the following:

1. Significant scope exists for reducing the energy/GNP relationship of the U.S. approaching those of Europe and Japan. Some structural differences will remain such as the mix of transportation activities, but most major energy intensity reducing technologies should be transferable.

2. Significant scope exists. for efficiency improvements in Europe and Japan, though not as great as in the U.S. This is due to a more efficient current capital stock in Europe and Japan, particularly automobiles and buildings.

3. Even with the substantial improvement in efficiency and fuel switching, when oil demand is compared to likely supplies, we appear to be entering a period of limited oil availability.

4. The major limiting factor in equilibrating supply and demand is the lead times associated with large scale supply additions or implementation of conservation technologies. 
Toward a Soft Landing

We have seen that despite appreciable implementation of conservation technologies, the world stands on the brink of a period in which the availability of oil supplies to meet desired demand will be uncertain and subject to political limitations which could be imposed by a small number of critical oil producers.

Based on the WAES analysis, the imposition of such a cutoff would result in an inconsistent case; this means that in order to equilibrate supply and demand, one or more of the following conditions would prevail:

1. World economic growth would drop below the reference case levels;

2. Oil prices would rise substantia1ly in real terms; and

3. Governments would be forced to adopt energy policies more stringent than the maximum judged politically feasible by the WAES national teams.

These conditions could quite likely be accompanied by severe inflation, unemployment, and disruption of normal economic activity. Such considerations would be severe if the limitations on oil availability were imposed suddenly or involved actual reductions from current output; they would be less severe if they involved simple leveling off of OPEC output.

What is the role of conservation in this environment?

Conservation must be pursued as part of a total program for transition from oil based, rapid energy growth to a sustainable energy economy based on maximum efficiency and declining oil availability. If we are to avoid potentially massive disruptions of industrial economies, we must engineer a soft landing from the oil based, high growth energy patterns of the past.

The key to achieving this transition is acceleration of the rate of turnover of the energy consuming capital stock in order to replace it with 
more efficient equipment. The WAES scenarios include a substantial amount of this in response to existing energy prices and vigorous government conservation policies. However, in response to the tight world oil situation anticipated in the eighties, conservation programs of the following sort need to be considered:

1. Methods to speed up the turnover of the automobile stock, replacing the existing fleet with economically justified, higher efficiency vehicles. The tax/rebate proposal of the administration is the right general approach, but strenghtening of its provisions should be examined.

2. Incentives to improve energy performance of buildings. These have been well received by Congress and should be in place soon.

3. Direct government action to improve buildings where incentives are not applicable. This includes those such as public buildings; low income housing; and rental units.

4. Increased investment tax credits for industry. While it is probably inefficient to offer special incentives: for energy conserving equipment relative to other equipment, industrial investment particularly in energy intensive basic industies - has been stagnant in this country, and investment in energy conservation has been hurt as a consequence.

5. Completion of a program to develop backstop technologies for oil. These would be alternative technologies such as syncrude from coal and oil shale which may not be economically competitive at present but which would if available in large quantities - serve to establish an upper limit on the long run price of oil. Federal pricing regulation could then be directed toward managing a smooth transition to such a long run equilibrium price. This will serve to provide a major incentive to accelerate implementation of conservation technologies. 
6. Intensive studies of more radical low energy growth futures. It is well established that known conservation technologies can reduce the intermediate term energy coefficient to 0.5 or so; we need to move further toward exploring possible structural changes in the economy, highly advanced conservation technologies now in the RD \& D phase, or other measures which might enable us to estimate very long term minimum energy requirements for specific activities. If lower energy consumption would have a cost in terms of certain GNP components, we need to know this also. The Energy Policy Project Zero Energy Growth scenarios and the forthcoming National Academy of Sciences Committee on Nuclear and Alternative Energy Strategies report offer useful beginnings in this direction.

These are not recommendations adopted by WAES as a group, but rather conclusions this author has reached as a result of participation in WAES. Further research is needed to identify preferred approaches to accelerating turnover of the energy conserving capital stock. In particular, further investigation is required to assess whether programs of this sort would require unrealistic increases in investment and whether there would be any significant economic costs arising from premature retirement of existing capital.

\section{Acknowledgements}

This paper summarizes and discusses results of research performed by many persons within WAES, and I am indebted to all of them. However, I especially wish to thank Professor Carroll Wilson of M.I.T., who conceived WAES and invited me to participate as a consultant on the organization of these demand studies; Professor Ben Elbek of the Niels Bohr Institute who prepared internal working papers analyzing these demand studies which 
suggested some approaches to this topic; and Paul S. Basile of the WAES staff who edited the national studies for publication. The diagrams in this paper were prepared by WAES consulting artists. Carmen Zopf ably typed repeated drafts, simultaneously meeting deadlines and maintaining her good humor. The interpretations of the results which I have made and any remaining errors are my responsibility alone and are not the responsibility of the WAES group.

\section{References}

1. Workshop on Alternative Energy Strategies, Energy Demand Studies: Major Consuming Countries. Cambr1dge, M.I.T. Press, 1976.

2. Workshop on Alternative Energy Strategies, Energy: Global Prospects, 1985-2000. New York, McGraw-Hill, 1977.

3. Workshop on Alternative Energy Strategies, Energy Supply to the Year 2000: Global and National Studies. Cambridge, M.I.T. Press, 1977.

4. Workshop on Alternative Energy Strategies, Energy Supply-Demand Integrations to the Year 2000: Global and National Studies. Cambridge, M.I.T. Press, 1977. 
APPENDIX

WAES Demand Study Worksheets 


\section{Workshop on Alternative Energy Strategies}

Tolughone $(617)$ 253-3418
Carroll L. Wilson. Director

MIT. 1 Amhersi Street

Cambridge

Massachusetts 02139

Cable: MIT WAES CAM

Page 1 of 6
NATIONAL DEMAND STUDY WORKSHEETS REVISION 3

WORKSHEET FOR COUNTRY

YEAR

PRICE CASE

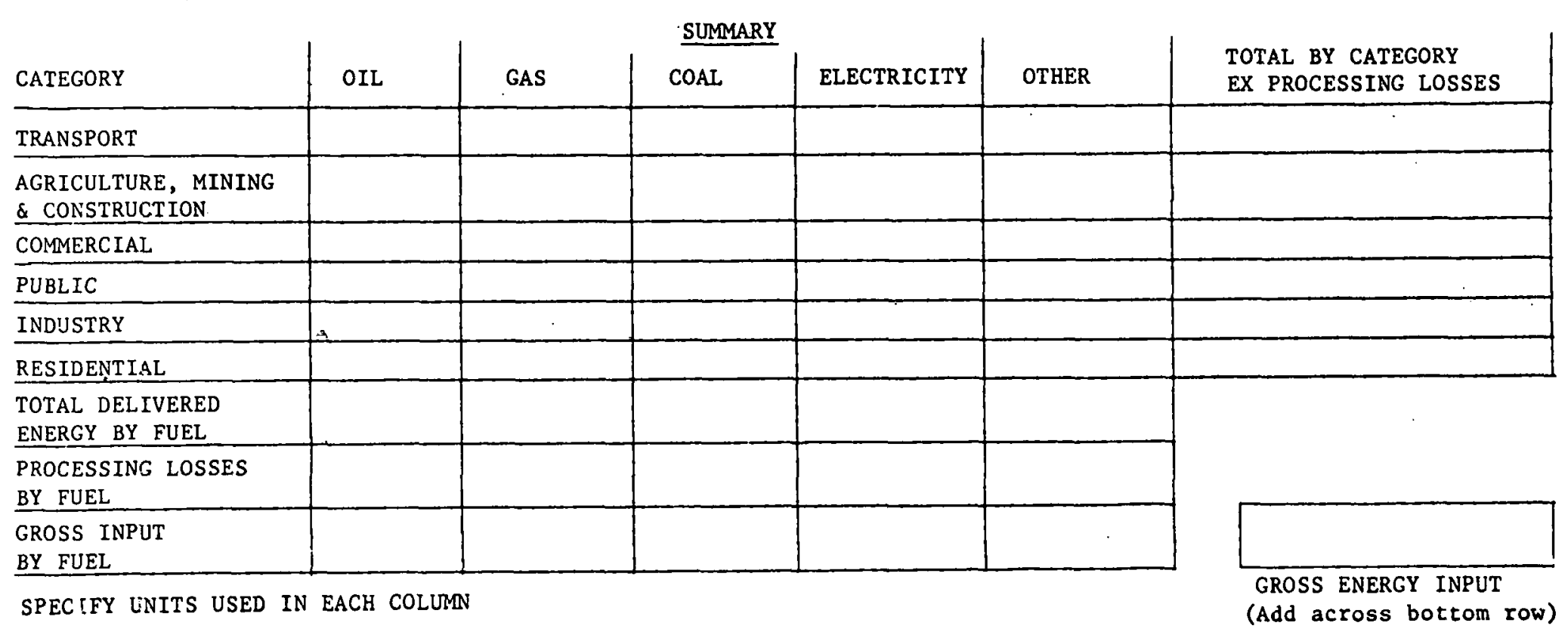


Page 2 of 6

WORKSHEET FOR: PRICE CASE

CATEGORY: TRANSPORT (A)
CATECORY: TRANSPOR (A) (B)

\section{POLICY OR OTHER ASSUMPTIONS}

(B)

DISTANCE/AUTO/YR

\begin{tabular}{l|l|l|l} 
& & & \\
\hline URBAN AUTO & & & \\
\hline & & & \\
\hline & ACTIVITY LEVEL & \% ELECTRIFIED & LOAD
\end{tabular}

(C)
(D)

\begin{tabular}{|l|l|l|l|l|}
\hline & FRACTION U1 OR R & ENERGY/DISTANCE & FUSSIL FUEI & ELECTRICITY \\
\hline & & & & \\
\hline & & & \\
\hline & & & & \\
\hline & & & & \\
\hline & & & \\
\hline & & & & \\
\hline & & & & \\
\hline & & & & \\
\hline & & & & \\
\hline & & & & \\
\hline & & & & \\
\hline & & & & \\
\hline
\end{tabular}

URBAN BUS

RAIL PASSENGERS

AIR TRAVEL-D ${ }^{3}$

AIR TRAVEL-I ${ }^{4}$

SHIP TRAVEL

RAIL FREIGHT

AIR FREIGHT-D

AIR FREIGHT-I

TRUCK-LOCAL

TRUCK-INTERCITY

SHIP FREIGHT-D

SHIP FREIGHT-I

MISCELLANEOUS

SPECIFY UNITS USED IN EACH COLUMN

1. U=Urban

2. $R=R u r a 1$

4. I=International

(5) $\underset{w}{\omega}$ 
WORKSHEET FOR: COUNTRY

YEAR

ECONOMIC CASE

PRICE CASE

POLICY OR OTHER ASSUMPTIONS

CATEGORY: AGRICULTURE, FORESTRY, AND FISHING (ISIC MAJOR DIVISION 1)

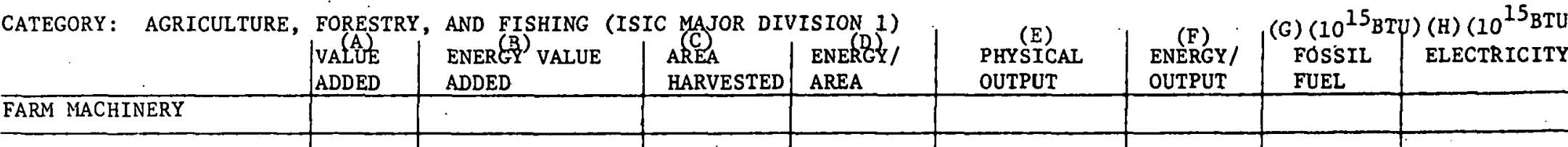

GREENHOUUSES

OTHER AGRICULTURAL USE

FORESTRY. (ISIC 12)

FISHING BOATS (ISIC 13)

OTHER FISHING

USE (ISIC 13)

Total Fertilizer (tons)

CATEGY (A) (B)

(C)

(D) $\left(10^{15} \mathrm{BTU}\right)$

$\left(10^{\left.15_{\mathrm{BTU}}\right)} \quad\left(10^{\left.15_{\mathrm{BTU}}\right)}\right.\right.$

HANLIINi is INTERNAL

TRINSPURTATION

CIFER ENER.GY USE

C

D)

TOTAL

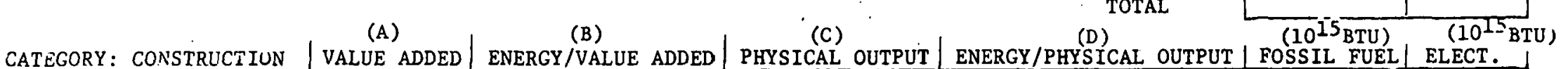

\begin{tabular}{l|l|l|l|}
$\begin{array}{c}\text { HANDLING \& INTERNAL } \\
\text { TRANSFORTATION }\end{array}$ & & & \\
\hline OTHER ENERGY USF & VALUE ADDED & ENERGY/VALUE ADDED & PHYSICAL OUTPUT \\
\hline
\end{tabular}

ENERGY

OUTPUT FOSSIL FUE

\begin{tabular}{|l|l|}
\hline FOSSIL FUEL & ELECT. \\
\hline & \\
\hline & \\
\hline & \\
\hline & \\
\hline
\end{tabular}

AGRICULTURE, MINING \& CONSTRUCTION TOTAL

TOTAL 
DATE

Page 4 of 6

\begin{abstract}
WORKSHEET FOR: COUNTRY
\end{abstract}
YEAR

ECONOMIC CASE

PRICE CASE

POLICY OR OTHER ASSUMPTIONS

\begin{tabular}{l|c|c} 
CATEGORY COMMERCIAL & FLOOR AREA & HEAT GAIN OR LOSS/AREA \\
\hline SPACE HEAT-FOSSIL FUEL & & \\
\hline SPACE HEAT-ELECTRICITY & & \\
\hline AIR COND.-FOSSIL FUEL & & \\
\hline AIR COND.-ELECTRICITY & & ENERGY/AREA \\
\hline LIGHTING & & \\
\hline MISCELLANEOUS & & \\
\hline PRESENTLY UNKNOWN & & \\
\hline
\end{tabular}

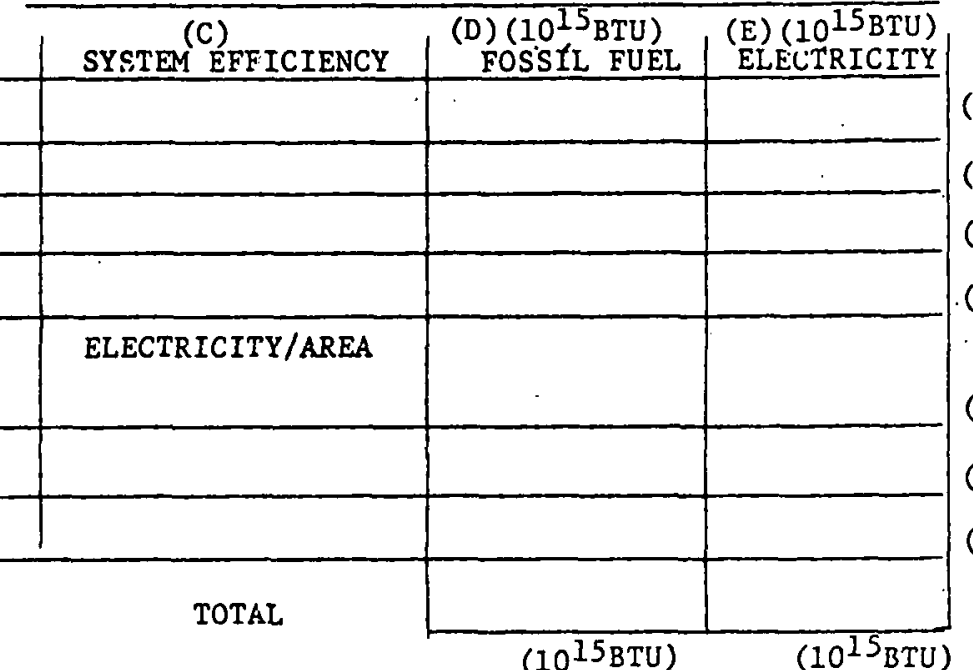

\begin{tabular}{|c|c|c|c|c|c|}
\hline CATEGORY: PLBLIC & FLOOR AREA & HEAT GAIN OR LOSS/AREA & SYSTEM EFFICIENCY & $\begin{array}{c}\left(10^{15} \mathrm{BTU}\right) \\
\text { FOSSIL FUEL }\end{array}$ & $\begin{array}{c}\left(10^{\left.1 S_{\text {BTU }}\right)}\right. \\
\text { ELECTRICITY } \\
\end{array}$ \\
\hline \multicolumn{6}{|c|}{ SPACE HEAT-FOSSIL FUEL } \\
\hline \multicolumn{6}{|c|}{ SPACE HEAT-ELECTRICITY } \\
\hline \multicolumn{6}{|c|}{ AIR COND.-FOSSIL FUEL } \\
\hline \multicolumn{6}{|c|}{ AIR COND.-ELECTRICITY } \\
\hline LIGHTING & & ENERGY/AREA & ELECTRICITY/AREA & & \\
\hline \multicolumn{6}{|l|}{ MISCELLANEOUS } \\
\hline \multicolumn{6}{|l|}{ PRESENTLY UNKNOWN } \\
\hline SPECIFY UNITS USED & LUMN & & TOTAL. & & \\
\hline
\end{tabular}


DATE

WORKSHEET FOR:

COUNTRY

YEAR

ECONOMIC CASE

PRICE CASE

POLICY OR OTHER ASSUMPTIONS

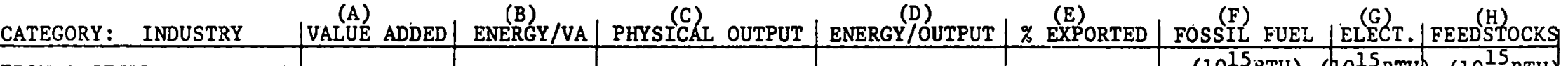

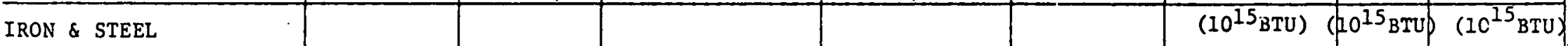

(ISIC

NON FERROUS METALS

(ISIC 372)

PAPER \& ALLIED

(ISIC 34)

CHEMICALS \& ALLIED

(ISIC 35 minus ISIC 353 .

MINERAL PRODUCTS

(ISIC 36)

FOOD \& RELATED

(ISIC ii)

TRAVSPORT EQPT.

(ISIC 384)

KLY JNLUSTRY,

N.)....*

KEY INDUSTRY,

N.E.C.*

MISC. MFG.

*SPECIFY KEY INDIISTRIES

SPECTFY UNITS USED IN EACH COLUMN

N.E.C. =Nut Elsewhere Classified

TOTAL 


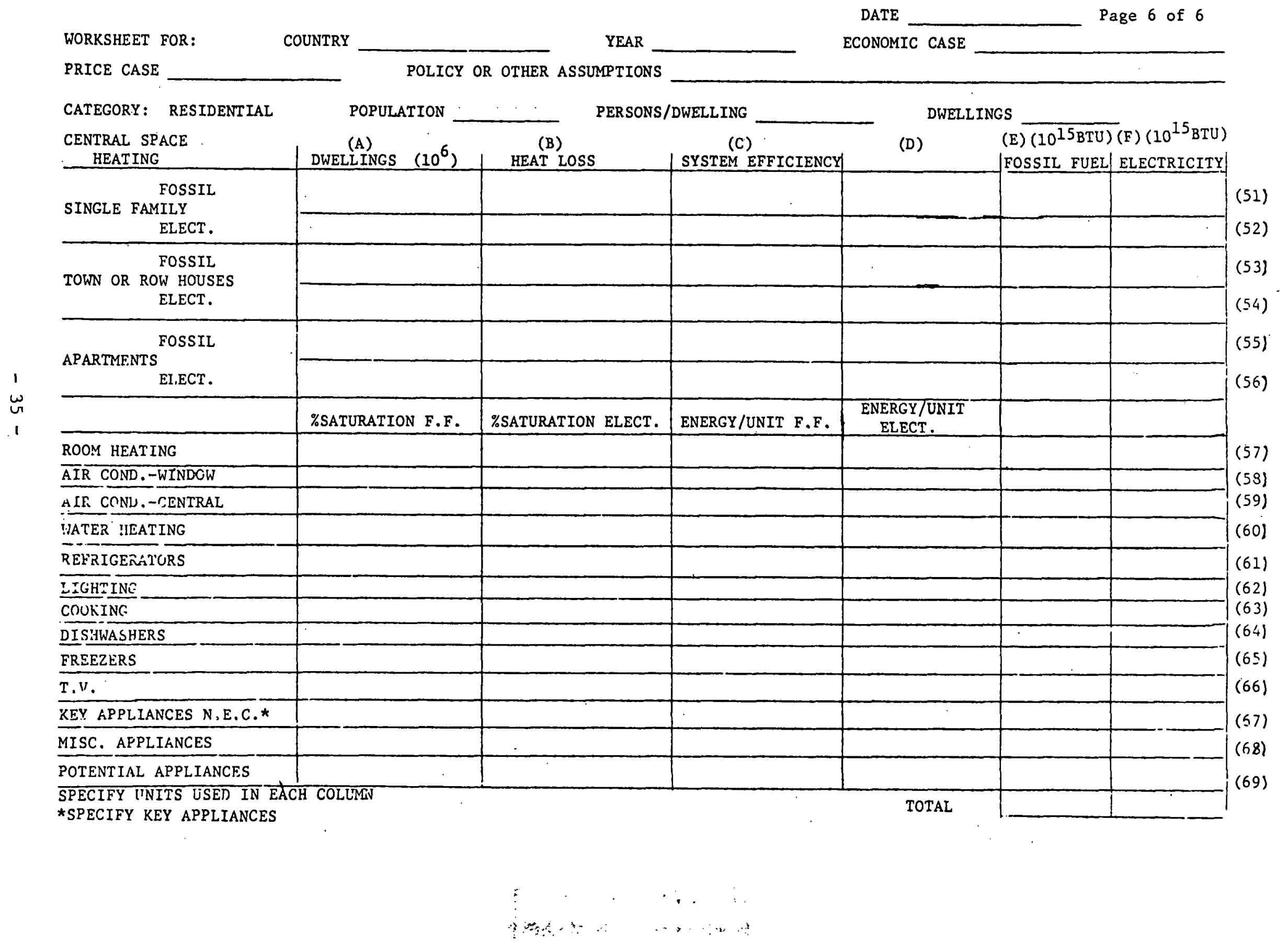


THIS PAGE

\section{WAS INTENTIONALLY LEFT BLANK}




\section{APPENDIX}

WAES Participants, Associates, and Staff 
PROJECT DIRECTOR

Carroll L. Wilson

Massachusetts Institute of Technology

\section{PARTICIPANTS}

Canada

Mr. Marshall A. Crowe

Chairman, National Energy Board

Mr. Maurice F. Strong

Chairman, Petro-Canada

Denmark

Professor Bent Elbek

Niels Bohr Institute

\section{Finland}

Professor Jorma Routti

Helsiaki University of Technology

\section{France}

M. Jean Couture

Conseiller du Président

Société Générale

M. Jean-Marie Martin

Director, Institut Economique et Juridique de l'Energie

Centre National de la Recherche Scientifique

\section{Germany}

Director Dr. Hans Detzer

Head of Central Planning

Badische Anilin \& Soda Fabrik AG

Professor Heinrich Mandel

Member of the Board of Directors

Rheinisch-Westfälisches

Elektrizitätswerk AG

Professor Hans K. Schneider

Director, Institute of Energy Economics

University of Cologne

Iran

Dr. Khodadad Farmanfarmaian
Italy

Professor Umberto Colombo

Director, Research \& Development

Division

Montedison

Professor Sergio Vaccà

Director, Istituto di Economia delle Fonti de Energia

Università L. Bocconi, Milano

Japan

Mr. Toshio Doko

President, Japan Federation of Economic Organizations (Keidanren)

Mr. Shuzo Inaba

President, Industrial Research Institute

Mr. Soichi Matsune Chairman, Committee on Energy

Japan Federation of Economic Organizations (Keidanren)

Mr. Tatsuzo Mizukami President, Japan Foreign Trade Council, Inc.

Dr. Saburo Okita President, The Overseas Economic Cooperation Fund

Mr. Masao Sakisaka President, National Institute for Research Advancement

Mr. Shigefumi Tamiya

Advisor to the Chairman Enrichment and Reprocessing Group

\section{Mexico}

Ing. Juan Eibenschutz

Executive Secretary

Mexican National Energy Commission

Dr. Victor Urqùidi

President, El Colégio de México 
The Netherlands

Dr. A. A. T. van Rhijn

Deputy Director General for Energy

Ministry of Economic Affairs

Netherlands/U.K.

Mr. J. C. Davidson

Former Director, Shell International

Petroleum Company, Ltd.

Royal Dutch/Shell Group

Norway

Mr. Christian Sommerfelt

Chairman

Elkem-Spigerverket $A / S$

Sweden

Mrr. Erland Waldenström

Chairman

Gränges $\mathrm{AB}$

Cinited Kingdom

Mr. Robert Belgrave

Policy Adviser to the Board

British Petroleum Company, Ltd.

Professor Sir William Hawthorne

Master, Churchill College

University of Cambridge

United States

Mr. Thornton F. Bradshaw

President, Atlantic Richfield Company

Mr. Walker L. Cisler

Retired Chairman of the Board

Detroit Edison Company

Mr. John T. Connor

Chairman of the Board

Allied Chemical Corporation

Mr. Richard C. Gerstenberg

Director, General Motors Corporation

Dr. H. Guyford Stever ${ }^{1}$

Former Director, National Science Foundation

Venezuela

Dr. José A. Mayobre

Banco Central de Venezuela

Ing. Ulises Ramírez

Executive Secretary

National Energy Council

I From October 1974 to October 1976.

\section{ASSOCIATES}

Canada

Mr. Marc LeClerc

Director General, Special Projects

National Energy Board

Dr. John Ralston Saul

Special Assistant to the Chairman

Petro-Canada

Finiland

Mr. Seppo Hannus

Ministry of Trade and Industry

Energy Department

\section{France}

M. Bertrand Chateau

Institut Economique et Juridique de l'Energie

Centre National de la Recherche Scientifique

Dr. Maxime Kleinpeter

Eléctricité de France

Service Etudes Economique Générales

\section{Germany}

Dr. Georg Klotmann

Strategic Planning Department

Badische Anilin \& Soda Fabrik AG

Klaus-Peter Messer

Rheinisch-Westfälisches Elektrizitätswerk AG

Dr. Dieter Schmitt

Head, Institute of Energy Economics

University of Cologne

Mr. Paul H. Suding

Economist, Institute of Energy

Economics

University of Cologne

Italy

Dr. Oliviero Bernardini

Department of Technology Assessment

Research \& Development Division

Montedison

Dr. Riccardo Galli

Director, Department of Technology Assessment

Research \& Development Division

Montedison 
Mr. William Mebane

Department of Technology

Assessment

Research \& Development Division

Montedison

\section{Japan}

Mr. Shinichiro Aoyama

Senior Staff Researcher

National Institute for Research

Advancement

Mr. Kenichi Matsui

Senior Staff Economist

The Institute of Energy Economics

Mr. Yasuhiro Murota

Staff Economist

The Japan Economic Research Center

Mr. Mitsuo Takei

Director, Research Affairs

The Institute of Energy Economics

Mr. Hisashi Watanabe

Executive Director

Japan Alternative Energy Strategies Organization

\section{Mexico}

Ing. Gerardo Bazán

Assessor

Mexican National Energy

Commission

Ing. Alberto Escofet

Assistant to the Executive Sccretary

Mexican National Energy

Commission

The Netherlands

Dr. André C. Sjoerdsma

Director, Future Shape of Technology

Foundation

Netherlands/U.K.

Mr. Alan W. Clarke

Energy \& Oil Economics Division

Shell International Petroleum Co., Ltd.

Royal Dutch/Sbell Group

Dr. Hans DuMoulin

Head of Energy \& Oil Economics Division

Shell International Petroleum Co., Ltd.

Royal Dutch/Shell Group
Dr. Gareth Price

Group Planning, Long Term Future

Shell International Petroleum

Co., Ltd.

Royal Dutch/Shell Group

Norway

Mr. Henrik Ager-Hanssen

Deputy Managing Director

Statoil, Den Norske Stats

Oljeselskap A/S

Mr. Kai Killerud

Manager, Power Plant Engineering

Scandpower A/S

Swerden

Dr. Harry Albinsson

Energy Secretary

Federation of Swedish Industries

Mr. Bertil Eneroth

Special Assignments

Skandinaviska Enskilda Banken

United KIngdom

Mr. Michael Clegg

Manager, Systems Group, Corporate

Planning

British Petroleum Company, Ltd.

Dr. Edmund Crouch

Energy Research Group

Cavendish Laboratory

University of Cambridge

Dr. Richard J. Eden

Head, Energy Research Group

Cavendish Laboratory

University of Cambridge

Mr. Andrew R. Flower

Assistant Policy Analyst

Policy Review Unit

British Petroleum Company, Ltd.

United States

Mr. Walter F. Allaire

Director, Energy Resources

Allied Chemical Corporation

Mr. Steven Carbart ${ }^{2}$

Assistant Scientist

National Center for Analysis of Energy Systems

Brookbaven National Laboratory

Consultant on Demand Studies, October 1974 to December 1975; Advisor on U.S. Studies from Januasy 1976 to present. 
Dr. Paul P. Craig ${ }^{3}$

Director, Energy \& Resources Council

University of California

Dr. Henry L. Duncombe, Jr.

Ch:ef Fconomist

Gereral Motors Corporation

Mis. Sandra Fucigazt

Policy Analyst

Nulional Sitence Foundation

Mr. Edward D. Gritfith

ien:or Consultant-Policy Analysis and Forecasting

Atlantic Richtield Company

Dr. Kenneth Hoffmans

Head. National Center for Analysis of Energy Systems

Brookhaven National Laboratory

Dr. H. Paul Root

Director of Economic Studies

General Motors Corporation

Dr. David Steralight

Chief Economist

Atlantic Richfield Company

\section{Venezuela}

Dr. Felix Rossi-Guertero

Minister Counselor for

Petroleum Affairs

Venezuelan Embassy

Washington, D.C.

3 Associate from October 1974 to April 1976

- Associate from April 1976 to October 1976.

; Advisor on U.S. Studies from January 1976 to

present.

\section{STAFF}

MIT Program Staff

Mr. Robert P. Greene

Program/Administrative Officer

Mr. Paul S. Basile

Program Officer

Mr. William F. Martin

Program Officer

\section{MrT Support Staff}

Ms. Elaine R. Goldberg

Mis. Susan M. Leland

Ms. Hedy Walsh

MIT Research Assistants

Mr. Richard Cheston

Mr. Miles Harbur

European Support Staff

Ms. Karin Berntsen, Norway

Ms. Adriana Cavagna, Italy

Ms. Dalia Jackbo, Norway

Ms. Margaret Martirosi, United Kingdom 
